\title{
Antagonistic and Plant Growth-Promoting Effects of Bacillus velezensis BS1 Isolated from Rhizosphere Soil in a Pepper Field
}

\author{
Jong-Hwan Shin (D), Byung-Seoung Park, Hee-Yeong Kim, Kwang-Ho Lee, and Kyoung Su Kim (1) * \\ Division of Bio-Resource Sciences, BioHerb Research Institute, and Interdisciplinary Program in Smart Agriculture, \\ Kangwon National University, Chuncheon 24341, Korea
}

(Received on March 29, 2021; Revised on April 14, 2021; Accepted on April 14, 2021)

Pepper (Capsicum annuum L.) is an important agricultural crop worldwide. Recently, Colletotrichum scovillei, a member of the $C$. acutatum species complex, was reported to be the dominant pathogen causing pepper anthracnose disease in South Korea. In the present study, we isolated bacterial strains from rhizosphere soil in a pepper field in Gangwon Province, Korea, and assessed their antifungal ability against $C$. scovillei strain $\mathrm{KC} 05$. Among these strains, a strain named BS1 significantly inhibited mycelial growth, appressorium formation, and disease development of $C$. scovillei. By combined sequence analysis using $16 \mathrm{~S}$ rRNA and partial gyr $A$ sequences, strain BS1 was identified as Bacillus velezensis, a member of the $B$. subtilis species complex. BS1 produced hydrolytic enzymes (cellulase and protease) and iron-chelating siderophores. It also promoted chili pepper (cv. Nockwang) seedling growth compared with untreated plants. The study concluded that $B$. velezensis BS1 has good potential as a biocontrol agent of anthracnose disease in chili pepper caused by $C$. scovillei.

Keywords : Bacillus velezensis, biological control, Colleto-

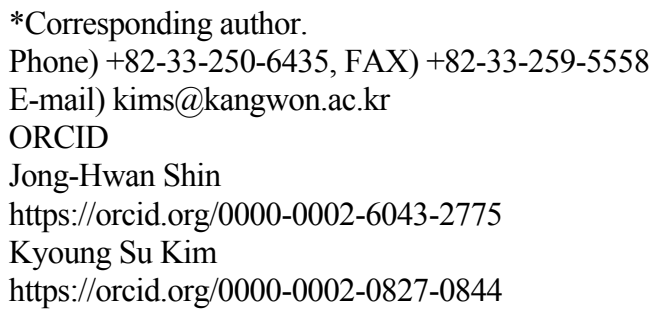

(c) This is an Open Access article distributed under the terms of the Creative Commons Attribution Non-Commercial License (http:// creativecommons.org/licenses/by-nc/4.0) which permits unrestricted noncommercial use, distribution, and reproduction in any medium, provided the original work is properly cited.

Articles can be freely viewed online at www.ppjonline.org. trichum scovillei, plant growth-promoting bacteria

Capsicum annum $\mathrm{L}$. is one of the five domesticated pepper species, which also include $C$. frutescens L., C. chinense Jacq., C. pubescens Ruiz \& Pav., and C. baccatum L. (Kraft et al., 2014). Among these, C. annuum is the most common and widely consumed species worldwide (Saxena et al., 2016). The major active compounds in peppers providing their pungent and spicy flavor are capsaicinoids (Barbero et al., 2016; Sanatombi and Sharma, 2008). Capsaicinoids include mainly capsaicin, dihydrocapsaicin, nordihydrocapsaicin, homocapsaicin, and homodihydrocapsaicin (Barbero et al., 2014). The most abundant of these compounds are capsaicin and dihydrocapsaicin (Laskaridou-Monnerville, 1999). Because of their attractive colors, flavors, and nutritive values, such as abundant vitamin C (Dias, 2012), peppers have been used extensively as fresh food, spice, or ingredient in a variety of dishes, such as kimchi (fermented cabbage) and gochujang (spicy red pepper paste) (Kwon et al., 2014).

Several fungal pathogens cause significant damage to immature (green) and mature (red) pepper fruit, stem, and root, resulting in significant losses of pepper fruit. These fungi include Botrytis cinerea, causing gray mold (Vagelas et al., 2009), Colletotrichum sp., causing anthracnose disease (Oo et al., 2017), Rhizoctonia solani, causing damping off (Rajkumar et al., 2008), and Sclerotinia sclerotiorum, causing sclerotinia rot (Kim and Cho, 2003). Among these, Colletotrichum is a large genus of filamentous ascomycetes fungi that causes anthracnose disease in a variety of crops, including pepper (Perfect et al., 1999). In Korea, the annual losses of pepper resulting from the disease are estimated to be more than US\$100 million (Kim et al., 2008). C. acutatum, C. coccodes, C. dematium, and C. gloeosporioides are known to cause pepper anthracnose in Korea, and C. acu- 
tatum is considered to be the major pathogen of the disease (Kim et al., 2008). However, C. scovillei, a member of the C. acutatum species complex, has recently been identified as the dominant pathogen causing pepper anthracnose in Korea (Oo et al., 2017; Shin et al., 2019). As it is a newly identified species in Korea, control strategies for this pathogen are limited.

Many chemical fungicides, such as azoxystrobin, captan, and ditioanon, have been applied in Korea to control pepper fungal diseases (http://www.koreacpa.org). Although fungicide application may result in quick and effective control of pepper fungal diseases, it has many negative effects, such as environmental pollution and residual toxic effects on animals and people (Mesnage et al., 2014; Wellman, 1977). As public concern for human health and well-being has been increasing, it is important to develop benign and eco-friendly control strategies, including the use of bacterial antagonists and plant extracts, which are considered to be safe in the environment and can be used within an integrated crop management system (de Souza et al., 2015; Stenberg et al., 2015). Biological control using bacterial antagonists is an especially promising alternative to chemical fungicides (Wisniewski et al., 2016). Bacillus, a large bacterial genus, is commonly used as a plant pathogen antagonist and plant growth-promoting bacteria because of its indole acetic acid production, phosphate solubilization, nitrogen fixation, and antibiotics production abilities, which enhance plant growth (Jiang et al., 2018; Stein, 2005).

In this study, an antagonistic bacterial strain of Bacillus velezensis was isolated from rhizosphere soil in a pepper field in Gangwon Province, South Korea, and evaluated for its antifungal and plant growth-promoting effects. The aim of this study was to find a potential biocontrol agent of pepper anthracnose caused by $C$. scovillei.

Soil samples were collected from a pepper field in Gangwon Province, South Korea, transported to the laboratory in a sterilized polythene bag, and stored at $4^{\circ} \mathrm{C}$. To isolate bacterial strains from soil samples, $1 \mathrm{~g}$ of soil was mixed with $10 \mathrm{ml}$ of sterile water and then serially diluted to $10^{-5}$. Then, $200 \mu$ of dilution was plated on a Luria-Bertani (LB) agar plate (tryptone $1 \%$, yeast extract $0.5 \%, \mathrm{NaCl} 0.5 \%$, agar $1.5 \%$ ). The plates were incubated at $28^{\circ} \mathrm{C}$ for 2 days. After incubation, single colonies were subcultured onto fresh LB agar plates, and isolates were stored in $25 \%$ glycerol at $-70^{\circ} \mathrm{C}$.

To analyze the inhibitory effects of isolates on fungal mycelial growth, mycelial agar plugs of $C$. scovillei $\mathrm{KC} 05$

Table 1. Antifungal activity of Bacillus velezensis BS1 on the mycelial growth of seven pathogens of pepper plants

\begin{tabular}{lc}
\hline Fungal pathogen & BS1 \\
\hline Colletotrichum scovillei & $+++^{\mathrm{a}}$ \\
C. gloeosporioides & +++++ \\
Botrytis cinerea & ++++ \\
Rhizoctonia solani & +++ \\
Sclerotinia sclerotiorum & ++++ \\
\hline
\end{tabular}

${ }^{\mathrm{a}}$ Determined by measuring the average inhibition rate of mycelial growth:,$+++ 40-50 \%$; ++++, 50-60\%; and,$+++++ 60-70 \%$ growth inhibition compared to the control treatments.

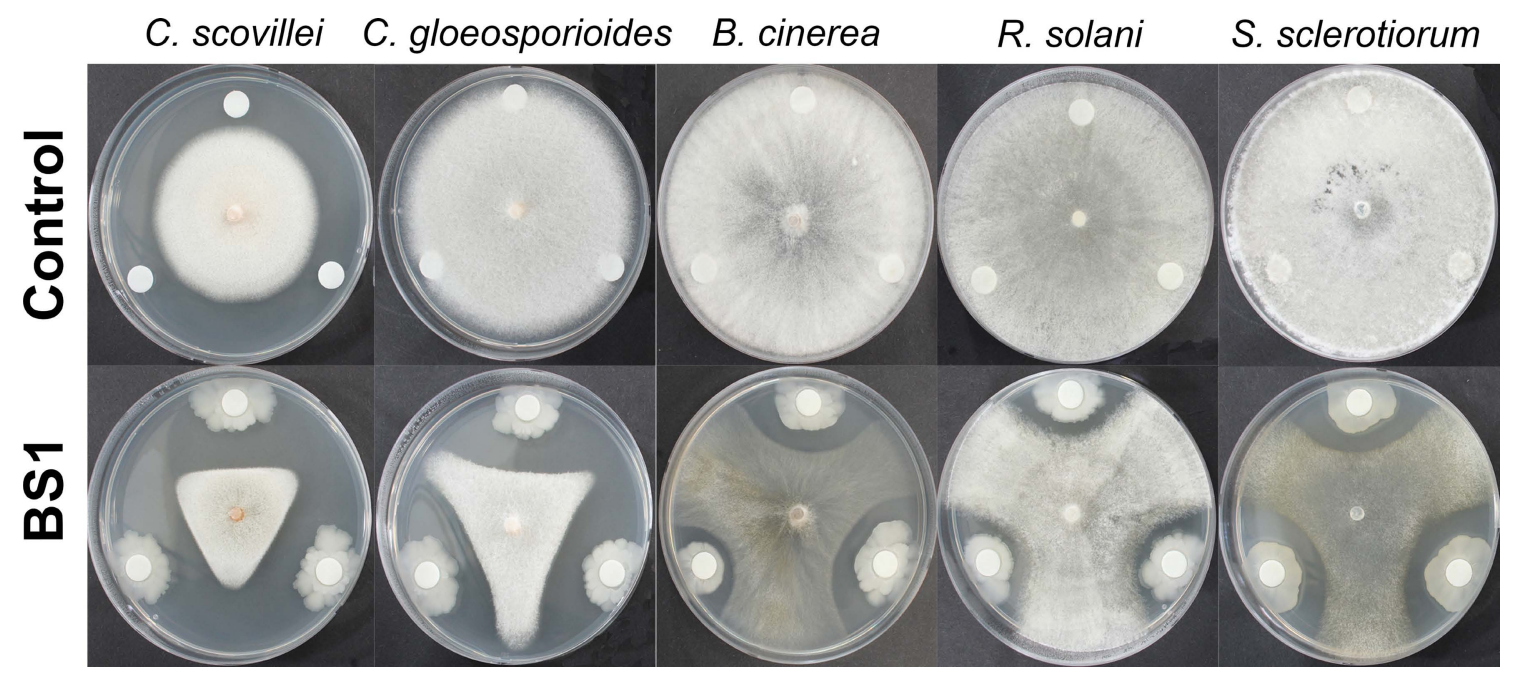

Fig. 1. Inhibitory effects of strain BS1 on fungal mycelial growth. Mycelial agar plugs of fungal pathogens (Colletotrichum scovillei, C. gloeosporioides, Botrytis cinerea, Rhizoctonia solani, and Sclerotinia sclerotiorum) were inoculated at the center of potato dextrose agar plates, and paper disks were placed at the edge of the plates. Drops $(20 \mu \mathrm{l})$ of BS1 suspension were added to the paper disks and incubated in the dark at $25^{\circ} \mathrm{C}$ for 4 days (B. cinerea, R. solani, and S. sclerotiorum) or 7 days (C. scovillei and C. gloeosporioides). 
(Shin et al., 2019), C. gloeosporioides (Han et al., 2015), B. cinerea (Kim et al., 2016), R. solani (KACC 40108), and $S$. sclerotiorum (KACC 40457) grown on potato dextrose agar (PDA; MBcell, Seoul, Korea) were transferred to the center of fresh PDA plates, and paper disks were placed at the edge of the PDA plates. Isolated bacterial strains were incubated in LB broth overnight $(16 \mathrm{~h})$ at $25^{\circ} \mathrm{C}$ with shaking at $150 \mathrm{rpm}$, and $10 \mu \mathrm{l}$ of bacterial culture was dropped on the paper disks. The cultures were incubated in the dark at $25^{\circ} \mathrm{C}$ for 4 days (B. cinerea, $R$. solani, and $S$. sclerotiorum) or 7 days (C. scovillei and C. gloeosporioides). The straight distance from the center to fungal hyphae edges in the treatment plates (TD) and the control plates (CD), respectively, was measured, and mycelial growth inhibition was calculated according to the following formula: Inhibition of growth $(\%)=(1-\mathrm{TD} / \mathrm{CD}) \times 100$ (Han et al., 2015). Each experiment was repeated three times, with three separate experiments. In total, 100 bacterial isolates were screened for antifungal activity against the fungal pathogens, and the most effective bacterial strain, BS1, was selected. BS1 exhibited high inhibitory effects on mycelial growth of $C$. scovillei $(45.60 \%), C$. gloeosporioides (63.09\%), B. cinerea (55.74\%), R. solani (49.43\%), and $S$. sclerotiorum (56.14\%) (Table 1, Fig. 1).

To identify strain BS1, 16S rRNA (Park et al., 2005) and partial gyrA (Chun and Bae, 2000) were amplified using the primers $27 \mathrm{~F} / 1492 \mathrm{R}$ and gyrA F/R (Table 2), respectively, in a $20-\mu l$ reaction mixture using $P f u$ polymerase (Elpis, Daejeon, Korea). DNA sequencing was performed by the National Instrumentation Center for Environmental Management at Seoul National University (NICEM, Seoul, Korea). The sequences obtained (GenBank accession numbers MW899044 and MW921480, respectively) were blasted against the National Center for Biotechnology Information (NCBI) database. The 16S rRNA and gyrA sequences from each bacterial species searched in the NCBI database were combined into a single sequence and aligned using ClustalW in the MEGA 7 program (Thompson et al., 1997). Finally, a phylogenetic tree was constructed using the combined sequences with the maximum-likelihood method (1,000 bootstrap replicates) (Tamura et al., 2011). The phylogenetic analysis revealed that strain BS1 grouped

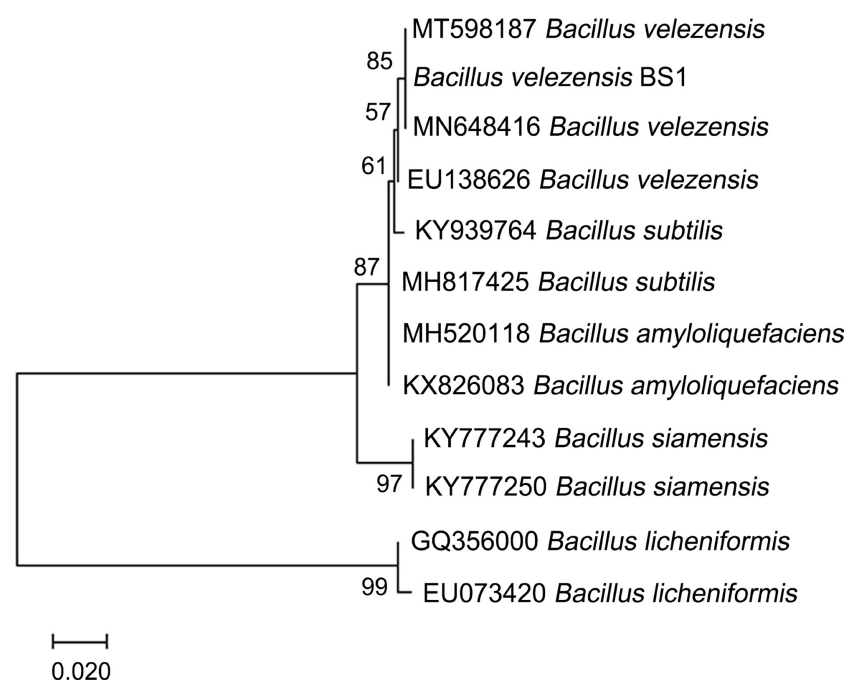

Fig. 2. Phylogenetic tree generated using the maximum-likelihood method based on a combined sequence analysis using $16 \mathrm{~S}$ rRNA and partial gyrA sequences of Bacillus species. The scale bar represents 0.010 nucleotide substitutions per site.

very closely with $B$. velezensis, having $99.8 \%$ similarity with $B$. velezensis strain F3A (Fig. 2).

Next, we evaluated the inhibitory effect of BS1 on appressorium formation of $C$. scovillei and disease development on pepper fruit. Conidia of $C$. scovillei $\mathrm{KC} 05$ were collected from a 5-day-old oatmeal agar plate ( $50 \mathrm{~g}$ of oatmeal and $25 \mathrm{~g}$ of agar per liter) with $5 \mathrm{ml}$ of sterile distilled water (SDW) and diluted to $5 \times 10^{4}$ conidia $/ \mathrm{ml}$ in SDW using a hemocytometer. BS1 was incubated overnight in $3 \mathrm{ml}$ of $\mathrm{LB}$ broth at $25^{\circ} \mathrm{C}$ with shaking at $150 \mathrm{rpm}$. The diluted conidial suspension was mixed with different concentrations $\left(1 \times 10^{4}, 10^{5}, 10^{6}\right.$, and $\left.10^{7} \mathrm{cfu} / \mathrm{ml}\right)$ of BS1 suspension, placed on hydrophobic cover slips, and incubated at $25^{\circ} \mathrm{C}$ in a moistened box (Fig. 3A). Appressorium formation was observed and counted at $16 \mathrm{~h}$ after inoculation. The experiment was repeated three times with three replicates per experiment ( $n \geq 100$ conidia per replicate). Conidia of $C$. scovillei treated with SDW as the control exhibited an appressorium formation rate of $87.3 \%$, (Fig. 3B). At concentrations of $1 \times 10^{6}$ and $1 \times 10^{7} \mathrm{cfu} / \mathrm{ml}$, the rate of appressorium formation was significantly lower $(13.3 \%$ and

Table 2. Primers used in this study

\begin{tabular}{lll}
\hline Target gene & Primer set & \multicolumn{1}{c}{ Sequence $\left(5^{\prime}-3^{\prime}\right)$} \\
\hline $16 \mathrm{~S}$ rRNA & $27 \mathrm{~F}$ & AGAGTTTGATCMTGGCTCAG \\
& $1492 \mathrm{R}$ & TACGGYTACCTTGTTACGACTT \\
gyrA & gyrA_F & CAGTCAGGAAATGCGTACGTCTT \\
& gyrA_R & CAAGGTAATGCTCCAGGCATTGCT \\
\hline
\end{tabular}


A Bacterial concentrations (cfu/ml)

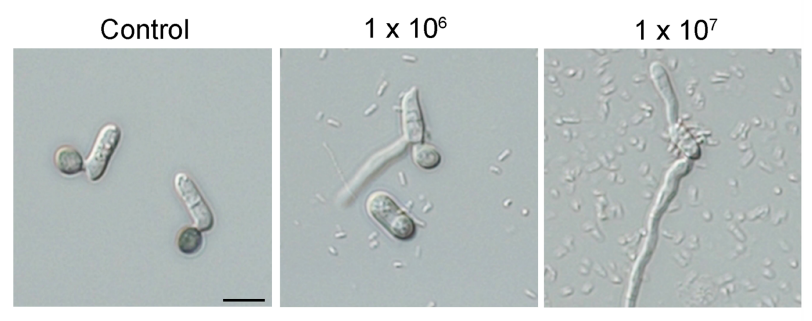

B

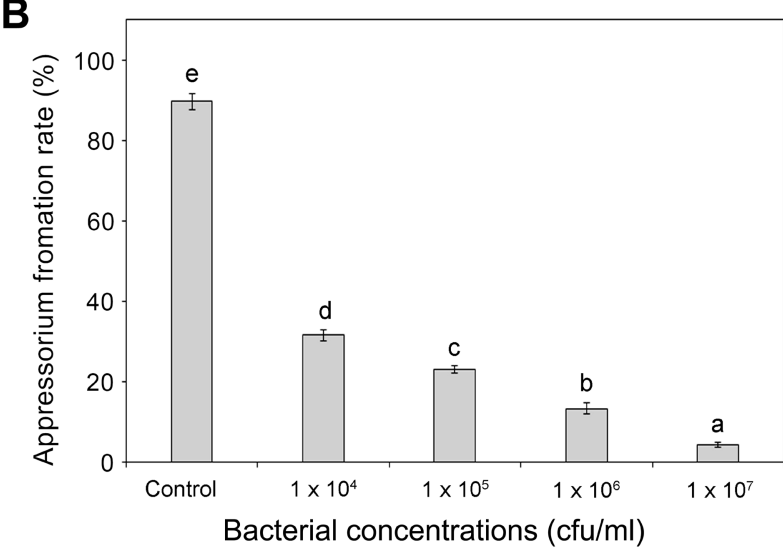

C

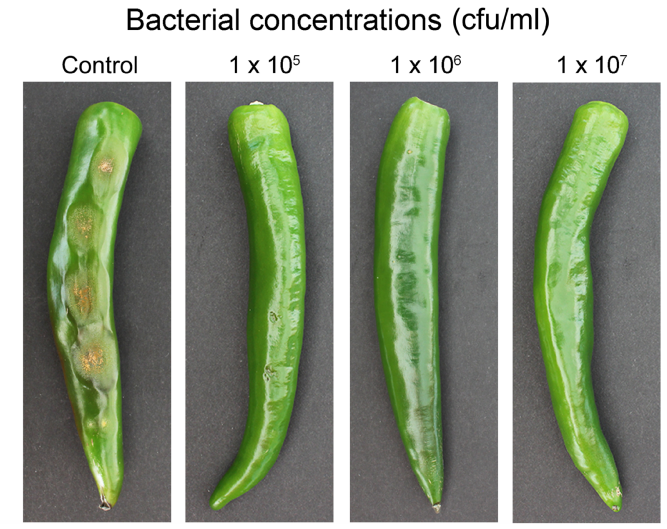

Fig. 3. Inhibitory effect of Bacillus velezensis BS1 on appressorium formation and disease development of Colletotrichum scovillei strain KC05. (A) Conidial suspension $\left(5 \times 10^{4}\right.$ conidia $\left./ \mathrm{ml}\right)$ of C. scovillei was mixed with different concentrations $\left(1 \times 10^{4}, 10^{5}\right.$, $10^{6}$, and $10^{7} \mathrm{cfu} / \mathrm{ml}$ ) of BS1 suspension, placed on cover slips, and incubated in a moistened box. Scale bar $=10 \mu \mathrm{m}$. (B) Appressorium formation was observed and counted at $16 \mathrm{~h}$ after inoculation. Error bars represent standard deviations of three replicates. Different letters on bars indicate significant differences according to Duncan's multiple range test at $P=0.05$. (C) Ability of BS1 to suppress disease development of $C$. scovillei on green pepper fruits (cv. Gilsang). Conidial suspension $\left(20 \times 10^{4}\right.$ conidia/ml) of C. scovillei was mixed with different concentrations $\left(1 \times 10^{5}, 10^{6}\right.$, and $10^{7} \mathrm{cfu} / \mathrm{ml}$ ) of BS1 suspension and inoculated onto pepper fruits. The result was observed after 10 days of incubation.
$4.3 \%$, respectively) than in the control. At a concentration of $1 \times 10^{5} \mathrm{cfu} / \mathrm{ml}$, the rate of appressorium formation was $31.6 \%$. We also evaluated the ability of BS1 to suppress disease development by $C$. scovillei $\mathrm{KC} 05$ on pepper fruit. We inoculated drops of fungal conidial suspension $(20 \times$ $10^{4}$ conidia/ml $)$ with different concentrations $\left(1 \times 10^{5}, 10^{6}\right.$, and $10^{7} \mathrm{cfu} / \mathrm{ml}$ ) of BS1 suspension on green pepper fruits (cv. Gilsang) and incubated them in a moistened box. After 10 days of incubation at $25^{\circ} \mathrm{C}$, typical sunken necrotic lesions (diameter of 10-13 mm) with orange conidial masses had developed on BS1-untreated pepper fruits, whereas anthracnose disease was completely inhibited at $1 \times 10^{7} \mathrm{cfu} /$ $\mathrm{ml}$ (Fig. 3C). At $1 \times 10^{5} \mathrm{cfu} / \mathrm{ml}$, anthracnose disease was significantly reduced. Only relatively small necrotic lesions (diameter of 1-2 mm) were present. Collectively, we concluded that strain BS1 effectively inhibits appressorium formation and disease development of C. scovillei.

Finally, the ability to produce extracellular enzymes and the plant growth-promoting activity of BS1 were examined. Cellulase activity was determined on carboxymethyl cellulose (CMC) agar plates, containing 1.2\% CMC, followed by flooding with $0.1 \%$ Congo Red solution according to the protocol described by Han et al. (2015). Siderophore production was measured using the chrome azurol S (CAS) agar assay, as described previously (Han et al., 2015). Protease activity (casein degradation) was evaluated on LB agar plates containing 3\% skim milk powder (Sokol et al., 1979). BS1 was incubated overnight in LB broth at $25^{\circ} \mathrm{C}$

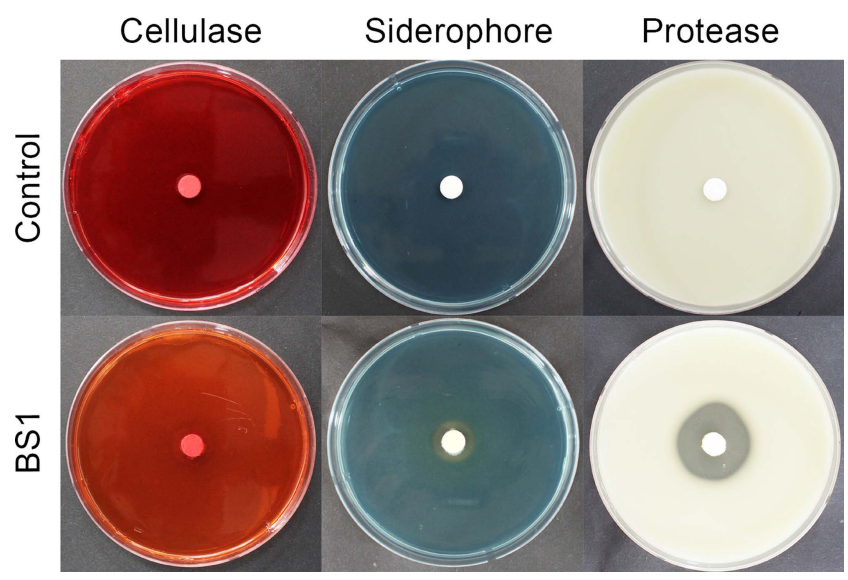

Fig. 4. Characterization of extracellular enzymes produced by Bacillus velezensis BS1. Cellulase activity was determined using carboxymethyl cellulose (CMC) agar plates containing 1.2\% $\mathrm{CMC}$, with flooding with $0.1 \%$ Congo red solution after 5 days. Protease production was examined on Luria-Bertani plates containing 3\% skim milk after 3 days. Siderophore production was examined on chrome azurol $\mathrm{S}$ agar plates after 5 days. 
Table 3. Effects of Bacillus velezensis BS1 inoculation on the growth of green pepper seedlings

\begin{tabular}{lccccc}
\hline Treatment & Plant height $(\mathrm{cm})$ & Leaf length $(\mathrm{cm})$ & Leaf width $(\mathrm{cm})$ & Root length $(\mathrm{cm})$ & Root fresh weight $(\mathrm{mg})$ \\
\hline BS1 & $107.8 \pm 7.35^{*}$ & $66.7 \pm 8.41^{*}$ & $37.1 \pm 5.32^{*}$ & $190.8 \pm 36.39^{*}$ & $114.3 \pm 39.11^{*}$ \\
Control & $76.3 \pm 5.2$ & $46.5 \pm 7.9$ & $25.5 \pm 4.0$ & $115.6 \pm 28.3$ & $30.1 \pm 8.12$ \\
\hline
\end{tabular}

Significant differences between the data of the BS1-treated and untreated control groups were determined by two-tailed $t$-tests with the $P$-value of less than 0.05 , as denoted by asterisks.

with shaking at $150 \mathrm{rpm}$, followed by centrifugation at 5,000 rpm for $10 \mathrm{~min}$, and then diluted to $1 \times 10^{7} \mathrm{cfu} / \mathrm{ml}$ in SDW. A paper disk was placed in the middle of each medium and loaded with a $20-\mu 1$ drop of BS1 suspension. After 3 days of incubation at $25^{\circ} \mathrm{C}$ on LB agar plates containing $3 \%$ skim milk powder, a clear zone around the colony of BS1 was observed, indicating that proteins were hydrolyzed by the bacteria (Fig. 4). BS1 also formed halo zones on CAS and CMC agar media after 5 days of incubation at $25^{\circ} \mathrm{C}$, indicating that $\mathrm{BS} 1$ could produce siderophores and cellulase. We also applied $20 \mathrm{~mL}$ of the diluted bacterial suspension $\left(1 \times 10^{7} \mathrm{cfu} / \mathrm{ml}\right)$ per pot at 7-day intervals on initially 1-week-old pepper seedlings (cv. Nockwang) and monitored their growth. After 5 weeks of application at $25^{\circ} \mathrm{C}$, the plant height, leaf length, leaf width, root length, and root fresh weight of the BS1-treated plants were measured and compared with those of the control plants (SDW applied). The experiment was repeated three times with three replicates. Application of BS1 significantly promoted pepper plant growth (Table 3, Fig. 5). The average plant height, leaf length, leaf width, root length, and root fresh weight of the BS1-treated plants were $107.8 \mathrm{~cm}, 66.7 \mathrm{~cm}$, $37.1 \mathrm{~cm}, 190.8 \mathrm{~cm}$, and $114.3 \mathrm{mg}$, whereas those of the untreated plants were $76.3 \mathrm{~cm}, 46.5 \mathrm{~cm}, 25.5 \mathrm{~cm}, 115.6 \mathrm{~cm}$, and $30.1 \mathrm{mg}$, respectively.

$B$. velezensis is an aerobic, gram-positive, endosporeforming bacterial species commonly found in soil. The species is one of the plant growth-promoting, biocontrol Bacillus species, so it has potential as a powerful biocontrol agent against plant pathogenic fungi that can serve as an alternative to chemical fungicides (Rabbee et al., 2019). Whole-genome sequencing of $B$. velezensis FZB42 has revealed a large number of biosynthetic gene clusters encoding antifungal compound-synthesis genes (Fazle Rabbee and Baek, 2020). Several antifungal compounds, including surfactins (Grady et al., 2019), fengycins (Adeniji et al., 2019), and bacillomycin D (Luna-Bulbarela et al., 2018), exerting control over pathogenic fungi have been identified. $B$. velezensis is an endophytic species that lives in various parts of plants, mainly in the tissues of roots (Chen et al., 2019), leaves (Li et al., 2020), stems (Kang et al., 2018), and even bulbs (Khan et al., 2020). Many plant endophytes have been reported to protect the host against plant fungal pathogens and increase plant growth and tolerance to environmental stresses, making them suitable biocontrol agents (Bandara et al., 2006; Cho et al., 2007; Li et al., 2016; Ullah et al., 2019).

In this study, we isolated antagonistic bacterial strains from rhizosphere soil in a pepper field in Gangwon Province, evaluated their antifungal ability, and selected bacterial strain BS1 as the most effective. We analyzed the 16S rRNA gene sequences of BS1 and confirmed that the strain belongs within the B. subtilis species complex, which includes species such as Bacillus amyloliquefaciens,
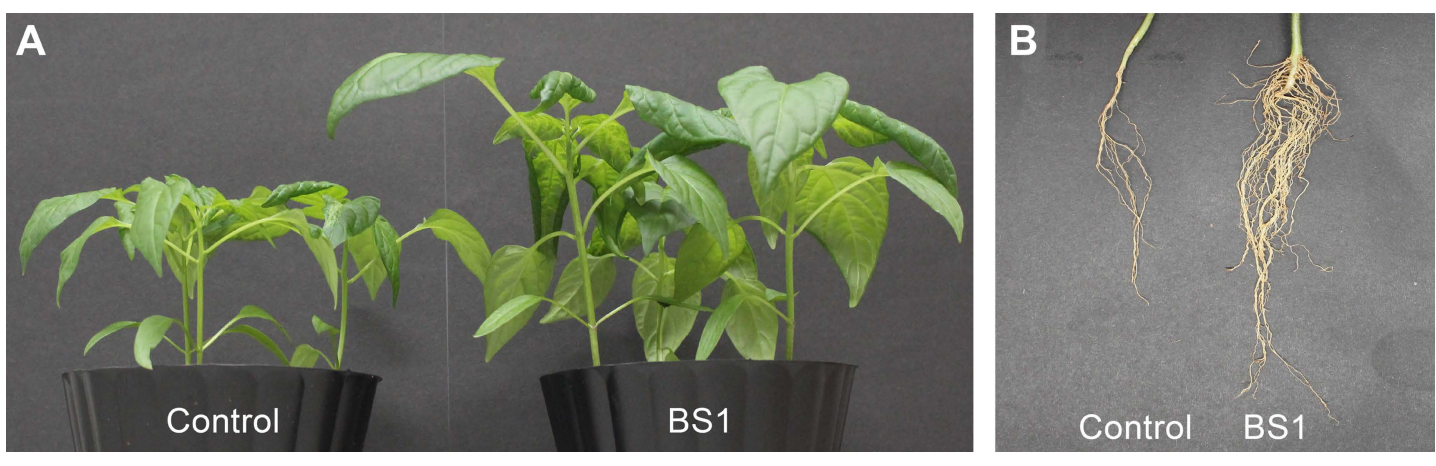

Fig. 5. Plant growth-promoting characteristic of Bacillus velezensis BS1. A volume of $20 \mathrm{ml}$ of bacterial suspension $\left(1 \times 10^{7} \mathrm{cfu} / \mathrm{ml}\right)$ was applied to pots containing initially 1-week-old pepper seedlings (cv. Nockwang) at 7-day intervals. Photographs were taken at 5 weeks after inoculation of the bacterial suspension. Effect of BS1 on growth of pepper plant (A) and roots (B). 
B. atrophaeus, B. velezensis, and B. siamensis (Fan et al., 2017). Members of the $B$. subtilis species complex are difficult to identify accurately at the species level based on the 16S rRNA gene because of their similar phenotypic characteristics and 16S rRNA gene sequences (Rooney et al., 2009). Chun and Bae (2000) performed a phylogenetic analysis using the partial gyrA sequences for 12 strains of $B$. subtilis-related species and confirmed that partial gyrA sequences can be used to identify $B$. subtilis-related species. Therefore, we analyzed the partial gyrA sequences of strain BS1 and related species, combined the gyrA sequences with 16S rRNA sequences, and identified the BS1 strain as B. velezensis.

Many antagonistic bacteria are capable of synthesizing and secreting hydrolytic enzymes, such as cellulase, protease, chitinase, and glucanase, which degrade fungal cell walls (Han et al., 2017; Jadhav and Sayyed, 2016). They also produce siderophores, low-mass iron-chelating compounds produced by microorganisms under low-iron conditions (Khan et al., 2018). Siderophores chelate ferric iron from minerals and organic compounds and make it available for plant cells, thereby promoting plant growth (Ahmed and Holmström, 2014). Some strains of B. velezensis have been reported to produce antifungal hydrolytic enzymes and siderophores. For example, Wang et al. (2020) reported that $B$. velezensis FKM10 isolated from rhizosphere soil of apple trees produced glucanase, protease, and siderophores and significantly inhibited growth of the pathogenic fungus Fusarium verticillioides. The BS1 strain consistently exhibited cellulase, protease, and siderophore production and inhibited the growth, appressorium formation, and disease development of C. scovillei, a pepper anthracnose pathogen. BS1 exhibited high inhibitory effects on mycelial growth of $B$. cinerea isolated from strawberry, $R$. solani isolated from lettuce (Lactuca sativa), and S. sclerotiorum isolated from lettuce ( $L$. sativa), indicating that the strain has a broad spectrum of antifungal activity against agriculturally important fungal pathogens. Bacillus species have received considerable attention because of their broad range of antifungal activities against agriculturally important fungal pathogens, including Fusarium oxysporum, Fusarium moniliforme, and Colletotrichum falcatum (Shahid et al., 2021). These results suggest that BS1 may be applied to other agricultural crops in addition to chili peppers. Beyond its antifungal ability, BS1 promoted chili pepper seedling growth, although the mechanism that contributed to the growth promotion still remains to be determined. Because of biological activity of microbial auxins (Glick, 2012), we tested whether BS1 suspension could promote growth of another plant, lettuce (L. sativa) seedlings. This revealed that BS1-mediated growth of lettuce seedlings was not significant (data not shown), which suggests that BS1 may not be associated with modulation of auxins. Because $C$. scovillei has only recently been identified as a Colletotrichum species causing anthracnose on pepper in Korea (Oo et al., 2017; Shin et al., 2019), there are few studies on biological or chemical controls against the pathogen. Our results provide basic information on biological control of $C$. scovillei causing pepper anthracnose. Additional studies are required to determine which antifungal compounds against C. scovillei are produced and the mechanisms by which $B$. velezensis $\mathrm{BS} 1$ promotes pepper plant growth.

\section{Conflicts of Interest}

No potential conflict of interest relevant to this article was reported.

\section{Acknowledgments}

This study was supported by the Korea Institute of Planning and Evaluation for Technology in Food, Agriculture, and Forestry through the Agri-Food Export Business Model Development Program (319088-3) and the Strategic Initiative for Microbiomes in Agriculture and Food (9180194), funded by the Ministry of Agriculture, Food and Rural Affairs.

\section{References}

Adeniji, A. A., Aremu, O. S. and Babalola, O. O. 2019. Selecting lipopeptide-producing, Fusarium-suppressing Bacillus spp.: metabolomic and genomic probing of Bacillus velezensis NWUMFkBS10.5. MicrobiologyOpen 8:e00742.

Ahmed, E. and Holmström, S. J. 2014. Siderophores in environmental research: roles and applications. Microb. Biotechnol. 7:196-208.

Bandara, W. M. M., Seneviratne, G. and Kulasooriya, S. A. 2006. Interactions among endophytic bacteria and fungi: effects and potentials. J. Biosci. 31:645-650.

Barbero, G. F., Liazid, A., Azaroual, L., Palma, M. and Barroso, C. G. 2016. Capsaicinoid contents in peppers and pepper-related spicy foods. Int. J. Food Prop. 19:485-493.

Barbero, G. F., Ruiz, A. G., Liazid, A., Palma, M., Vera, J. C. and Barroso, C. G. 2014. Evolution of total and individual capsaicinoids in peppers during ripening of the Cayenne pepper plant (Capsicum annuum L.). Food Chem. 153:200-206.

Chen, L., Shi, H., Heng, J., Wang, D. and Bian, K. 2019. Antimicrobial, plant growth-promoting and genomic properties of the peanut endophyte Bacillus velezensis LDO2. Microbiol. Res. 218:41-48.

Chun, J. and Bae, K. S. 2000. Phylogenetic analysis of Bacillus 
subtilis and related taxa based on partial gyrA gene sequences. Antonie van Leeuwenhoek 78:123-127.

Cho, K. M., Hong, S. Y., Lee, S. M., Kim, Y. H., Kahng, G. G., Lim, Y. P., Kim, H. and Yun, H. D. 2007. Endophytic bacterial communities in ginseng and their antifungal activity against pathogens. Microb. Ecol. 54:341-351.

de Souza, R., Ambrosini, A. and Passaglia, L. M. P. 2015. Plant growth-promoting bacteria as inoculants in agricultural soils. Genet. Mol. Biol. 38:401-419.

Dias, J. S. 2012. Nutritional quality and health benefits of vegetables: a review. Food Nutr. Sci. 3:1354-1374.

Fan, B., Blom, J., Klenk, H.-P. and Borriss, R. 2017. Bacillus amyloliquefaciens, Bacillus velezensis, and Bacillus siamensis form an "Operational group B. amyloliquefaciens" within the B. subtilis species complex. Front. Microbiol. 8:22.

Fazle Rabbee, M. and Baek, K.-H. 2020. Antimicrobial activities of lipopeptides and polyketides of Bacillus velezensis for agricultural applications. Molecules 25:4973.

Glick, B. R. 2012. Plant growth-promoting bacteria: mechanisms and applications. Scientifica 2012:963401.

Grady, E. N., MacDonald, J., Ho, M. T., Weselowski, B., McDowell, T., Solomon, O., Renaud, J. and Yuan, Z.-C. 2019. Characterization and complete genome analysis of the surfactin-producing, plant-protecting bacterium Bacillus velezensis 9D-6. BMC Microbiol. 19:5.

Han, J.-H., Park, G.-C. and Kim, K. S. 2017. Antagonistic evaluation of Chromobacterium sp. JH7 for biological control of ginseng root rot caused by Cylindrocarpon destructans. Mycobiology 45:370-378.

Han, J.-H., Shim, H., Shin, J.-H. and Kim, K. S. 2015. Antagonistic activities of Bacillus spp. strains isolated from tidal flat sediment towards anthracnose pathogens Colletotrichum acutatum and C. gloeosporioides in South Korea. Plant Pathol. J. 31:165-175.

Jadhav, H. P. and Sayyed, R. Z. 2016. Hydrolytic enzymes of rhizospheric microbes in crop protection. MOJ Cell Sci. Rep. 3:135-136.

Jiang, C.-H., Liao, M.-J., Wang, H.-K., Zheng, M.-Z., Xu, J.-J. and Guo, J.-H. 2018. Bacillus velezensis, a potential and efficient biocontrol agent in control of pepper gray mold caused by Botrytis cinerea. Biol. Control 126:147-157.

Kang, X., Zhang, W., Cai, X., Zhu, T., Xue, Y. and Liu, C. 2018. Bacillus velezensis CC09: a potential 'Vaccine' for controlling wheat diseases. Mol. Plant-Microbe Interact. 31:623-632.

Khan, A., Singh, P. and Srivastava, A. 2018. Synthesis, nature and utility of universal iron chelator - Siderophore: a review. Microbiol. Res. 212-213:103-111.

Khan, M. S., Gao, J., Chen, X., Zhang, M., Yang, F., Du, Y., Moe, T. S., Munir, I., Xue, J. and Zhang, X. 2020. The endophytic bacteria Bacillus velezensis Lle-9, isolated from Lilium leucanthum, harbors antifungal activity and plant growthpromoting effects. J. Microbiol. Biotechnol. 30:668-680.

Kim, J.-O., Shin, J.-H., Gumilang, A., Chung, K., Choi, K. Y. and Kim, K. S. 2016. Effectiveness of different classes of fungicides on Botrytis cinerea causing gray mold on fruit and vegetables. Plant Pathol. J. 32:570-574.

Kim, J.-T., Park, S.-Y., Choi, W.-B., Lee, Y.-H. and Kim, H.-T. 2008. Characterization of Colletotrichum isolates causing anthracnose of pepper in Korea. Plant Pathol. J. 24:17-23.

Kim, W. G. and Cho, W. D. 2003. Occurrence of sclerotinia rot in solanaceous crops caused by Sclerotinia spp. Mycobiology 31:113-118.

Kraft, K. H., Brown, C. H., Nabhan, G. P., Luedeling, E., Luna Ruiz, J. J., Coppens d'Eeckenbrugge, G., Hijmans, R. J. and Gepts, P. 2014. Multiple lines of evidence for the origin of domesticated chili pepper, Capsicum annuum, in Mexico. Proc. Natl. Acad. Sci. U. S. A. 111:6165-6170.

Kwon, D. Y., Jang, D.-J., Yang, H. J. and Chung, K. R. 2014. History of Korean gochu, gochujang, and kimchi. J. Ethn. Foods $1: 3-7$.

Laskaridou-Monnerville, A. 1999. Determination of capsaicin and dihydrocapsaicin by micellar electrokinetic capillary chromatography and its application to various species of Capsicum, Solanaceae. J. Chromatogr. A 838:293-302.

Li, F.-Z., Zeng, Y.-J., Zong, M.-H., Yang, J.-G. and Lou, W.-Y. 2020. Bioprospecting of a novel endophytic Bacillus velezensis FZ06 from leaves of Camellia assamica: production of three groups of lipopeptides and the inhibition against food spoilage microorganisms. J. Biotechnol. 323:42-53.

Li, X., Geng, X., Xie, R., Fu, L., Jiang, J., Gao, L. and Sun, J. 2016. The endophytic bacteria isolated from elephant grass (Pennisetum purpureum Schumach) promote plant growth and enhance salt tolerance of Hybrid Pennisetum. Biotechnol. Biofuels 9:190.

Luna-Bulbarela, A., Tinoco-Valencia, R., Corzo, G., Kazuma, K., Konno, K., Galindo, E. and Serrano-Carreón, L. 2018. Effects of bacillomycin D homologues produced by Bacillus amyloliquefaciens 83 on growth and viability of Colletotrichum gloeosporioides at different physiological stages. Biol. Control 127:145-154.

Mesnage, R., Defarge, N., Spiroux de Vendômois, J. S. and Séralini, G.-E. 2014. Major pesticides are more toxic to human cells than their declared active principles. Biomed. Res. Int. 2014:179691.

Oo, M. M., Lim, G., Jang, H. A. and Oh, S.-K. 2017. Characterization and pathogenicity of new record of anthracnose on various chili varieties caused by Colletotrichum scovillei in Korea. Mycobiology 45:184-191.

Park, H.-K., Shim, S.-S., Kim, S.-Y., Park, J.-H., Park, S.-E., Kim, H.-J., Kang, B.-C. and Kim, C.-M. 2005. Molecular analysis of colonized bacteria in a human newborn infant gut. J. Microbiol. 43:345-353.

Perfect, S. E., Hughes, H. B., O'Connell, R. J. and Green, J. R. 1999. Colletotrichum: a model genus for studies on pathology and fungal-plant interactions. Fungal Genet. Biol. 27:186198.

Rabbee, M. F., Ali, M. S., Choi, J., Hwang, B. S., Jeong, S. C. and Baek, K.-H. 2019. Bacillus velezensis: a valuable mem- 
ber of bioactive molecules within plant microbiomes. Molecules 24:1046.

Rajkumar, M., Lee, K. J. and Freitas, H. 2008. Effects of chitin and salicylic acid on biological control activity of Pseudomonas spp. against damping off of pepper. S. Afr. J. Bot. 74:268273.

Rooney, A. P., Price, N. P., Ehrhardt, C., Swezey, J. L. and Bannan, J. D. 2009. Phylogeny and molecular taxonomy of the Bacillus subtilis species complex and description of Bacillus subtilis subsp. inaquosorum subsp. nov. Int. J. Syst. Evol. Microbiol. 59:2429-2436.

Sanatombi, K. and Sharma, G. J. 2008. Capsaicin content and pungency of different Capsicum spp. cultivars. Not. Bot. Hort. Agrobot. Cluj. 36:89-90.

Saxena, A., Raghuwanshi, R., Gupta, V. K. and Singh, H. B. 2016. Chilli anthracnose: the epidemiology and management. Front. Microbiol. 7:1527.

Shahid, I., Han, J., Hanooq, S., Malik, K. A., Borchers, C. H. and Mehnaz, S. 2021. Profiling of metabolites of Bacillus spp. and their application in sustainable plant growth promotion and biocontrol. Front. Sustain. Food Syst. 5:605195.

Shin, J.-H., Han, J.-H., Park, H.-H., Fu, T. and Kim, K. S. 2019. Optimization of polyethylene glycol-mediated transformation of the pepper anthracnose pathogen Colletotrichum scovillei to develop an applied genomics approach. Plant Pathol. J. 35:575-584.

Sokol, P. A., Ohman, D. E. and Iglewski, B. H. 1979. A more sensitive plate assay for detection of protease production by Pseudomanas aeruginosa. J. Clin. Microbiol. 9:538-540.

Stenberg, J. A., Heil, M., Åhman, I. and Björkman, C. 2015. Optimizing crops for biocontrol of pests and disease. Trends
Plant Sci. 20:698-712.

Stein, T. 2005. Bacillus subtilis antibiotics: structures, syntheses and specific functions. Mol. Microbiol. 56:845-857.

Tamura, K., Peterson, D., Peterson, N., Stecher, G., Nei, M. and Kumar, S. 2011. MEGA5: molecular evolutionary genetics analysis using maximum likelihood, evolutionary distance, and maximum parsimony methods. Mol. Biol. Evol. 28:27312739.

Thompson, J. D., Gibson, T. J., Plewniak, F., Jeanmougin, F. and Higgins, D. G. 1997. The CLUSTAL_X windows interface: flexible strategies for multiple sequence alignment aided by quality analysis tools. Nucleic Acids Res. 25:4876-4882.

Ullah, A., Nisar, M., Ali, H., Hazrat, A., Hayat, K., Keerio, A. A., Ihsan, M., Laiq, M., Ullah, S., Fahad, S., Khan, A., Khan, A. H., Akbar, A. and Yang, X. 2019. Drought tolerance improvement in plants: an endophytic bacterial approach. Appl. Microbiol. Biotechnol. 103:7385-7397.

Vagelas, I., Papachatzis, A., Kalorizou, H. and Wogiatzi, E. 2009. Biological control of Botrytis fruit rot (Gray Mold) on strawberry and red pepper fruits by olive oil mill wastewater. Biotechnol. Biotechnol. Equip. 23:1489-1491.

Wang, C., Zhao, D., Qi, G., Mao, Z., Hu, X., Du, B., Liu, K. and Ding, Y. 2020. Effects of Bacillus velezensis FKM10 for promoting the growth of Malus hupehensis Rehd. and inhibiting Fusarium verticillioides. Front. Microbiol. 10:2889.

Wellman, R. H. 1977. Problems in development, registration, and use of fungicides. Annu. Rev. Phytopathol. 15:153-163.

Wisniewski, M., Droby, S., Norelli, J., Liu, J. and Schena, L. 2016. Alternative management technologies for postharvest disease control: the journey from simplicity to complexity. Postharvest Biol. Technol. 122:3-10. 